\title{
PEMULIHAN KEKUATAN OTOT PADA ATLET SEPAKBOLA
}

\author{
Atradinal $^{1}$, Rika Sepriani ${ }^{2}$ \\ ${ }^{1}$ Program Studi Pendidikan Jasmani Kesehatan dan Rekreasi, Fakultas Ilmu Keolahragaan, \\ Universitas Negeri Padang. Jalan Prof. Dr. Hamka Air Tawar Barat, Padang, 25132, \\ Indonesia. \\ ${ }^{2}$ Program Studi Pendidikan Jasmani Kesehatan dan Rekreasi, Fakultas Ilmu Keolahragaan, \\ Universitas Negeri Padang. Jalan Prof. Dr. Hamka Air Tawar Barat, Padang, 25132, \\ Indonesia.
}

Email: atr_pykh@yahoo.com ${ }^{1}$, rikasepriani@ fik.unp.ac.id ${ }^{2}$

\begin{abstract}
Abstrak
Sepakbola adalah salah satu cabang olahraga yang sangat populer di dunia. Pertandingan sepakbola dimainkan oleh dua tim yang masing-masing tim beranggotakan 11 orang. Seorang pemain diperbolehkan bergerak kemanapun juga di dalam lapangan, sehingga seorang pemain membutuhkan kondisi fisik yang prima. Kekuatan atau strenght adalah komponen kondisi fisik, yang menyangkut masalah kemampuan seseorang atlet pada saat mempergunakan otot-ototnya menerima beban dalam waktu kerja tertentu. Kekuatan merupakan salah satu unsur kondisi fisik yang sangat penting dalam sepakbola karena dapat membantu meningkatkan komponen-komponennya seperti kecepatan, kelincahan dan ketepatan. Selain kondisi fisik yang prima, hal yang sangat penting diperhatihan adalah recovery atau pemulihan. Proses pemulihan yang tepat akan dapat mengembalikan kekuatan otot atlet dalam suatu pertandingan.
\end{abstract}

Kata Kunci: Pemulihan, Kekuatan Otot, Sepakbola

\section{PENDAHULUAN}

Sepakbola adalah salah satu cabang olahraga yang sangat populer di dunia. Sepakbola telah banyak mengalami perubahan dan perkembangan dari bentuk sederhana dan primitif sampai menjadi permainan olahraga modern yang sangat digemari dan disenangi banyak orang. Berdasarkan buku pedoman yang diterbitkan PSSI (2009) sepakbola dimainkan oleh dua regu yang masingmasing terdiri dari 11 orang pemain dan salah satu pemainnya menjadi penjaga gawang yang dipimpin oleh seorang wasit, dibantu asisten 1 dan asisten 2, serta satu orang wasit cadangan. Dimainkan di atas lapangan rumput berbentuk persegi panjang dengan ukuran panjang 100-110 meter dan lebar 64-75 meter yang dibatasi garis selebar 12 centimeter serta dilengkapi 2 buah gawang yang tingginya 2,44 meter dan lebar 7,32 meter. Permainan sepakbola berlangsung dalam 2 babak yang masing-masing babaknya 45 menit dengan waktu istirahat 15 menit.

Masing-masing tim pada sepakbola mempertahankan sebuah gawang dan mencoba menjebolkan gawang lawan (Luxbacher, 2011). Seorang pemain diperbolehkan bergerak kemanapun juga di dalam lapangan, walaupun masing-masing memiliki tanggung jawab khusus. Maka, berdasarkan pernyataan tersebut seorang pemain membutuhkan kondisi fisik yang prima untuk menunjang kemampuan pemain dalam menampilkan keterampilan bermain sepakbola dengan maksimal, seperti keterampilan menendang, mengontrol, mendribel, maupun melakukan tendangan ke gawang.

Kekuatan adalah kekuatan otot yang membangkitkan tenaga/kekuatan/force terhadap suatu tahanan. Menurut Faizal (2012) kekuatan atau strenght adalah komponen kondisi 
fisik, yang menyangkut masalah kemampuan seseorang atlet pada saat mempergunakan otot-ototnya menerima beban dalam waktu kerja tertentu. Kekuatan merupakan salah satu unsur kondisi fisik yang sangat penting dalam berolahraga karena dapat membantu meningkatkan komponen-komponen seperti kecepatan, kelincahan dan ketepatan.

Kekuatan adalah kemampuan otot-otot atau sekelompok otot untuk mengatasi suatu beban atau tahanan dalam menjalankan aktivitas latihan. Kekuatan harus mutlak diperlukan pada setiap atlet untuk semua cabang olahraga. Kekuatan otot merupakan komponen penting dari kesegaran jasmani, karena tingkat penyesuaian kemampuan terjadi sesuai dengan proporsi dari kualitas dan jumlah serabut otot. Kekuatan dapat diartikan sebagai kualitas tenaga otot atau sekelompok otot dalam membangun kontraksi secara maksimal untuk mengatasi beban yang datang baik dari dalam maupun dari luar. Pada otot tungkai, gerakan yang dilakukan akan menghasilkan gerakan aktivitas seperti menendang, berjalan, melompat dan lain sebagainya. Dimana garakan tersebut dibutuhkan dalam melakukan gerakan olahraga, terutama cabang olahraga yang dominan menggunakan kaki separti: sepakbola, pencaksilat, bersepada dan masih banyak lainnya. Andi Suhendro (2004) mengatakan salah satu unsur kondisi fisik yang perlu dilatih terlebih dahulu adalah unsur kondisi fisik kekuatan, karena kekuatan memiliki peranan yang penting dalam melindungi atlet dari cedera serta membantu stabilitas sendi-sendi

Otot merupakan suatu organ atau alat yang memungkinkan tubuh dapat bergerak. Sebagian otot tubuh ini melekat pada kerangka otot yang dapat bergerak secara aktif sehingga dapat menggerakan bagian-bagian kerangka dalam suatu letak tertentu. Otot dapat mengadakan kontraksi dengan cepat, apabila ia mendapatkan rangsangan dari luar berupa rangsangan arus listrik, rangsangan mekanis, dingin dan lain-lain. Tarwoto (2009) mengatakan bahwa dalam keadaan sehari-hari otot ini bekerja atau berkontraksi menurut pengaruh atau perintah yang datang dari susunan saraf motoris. Harsono dalam Yoga Parwata (2015) kontraksi otot dapat digolongkan dalam tiga kategori yaitu: (1) kontraksi isometris, dalam kontraksi isometris otot-otot tidak memanjang atau memendek sehingga tidak nampak suatu gerakan yang nyata, atau dengan perkataan lain tidak ada jarak yang ditempuh. Kontraksi ini disebut juga kontraksi statis. (2) kontraksi isotenis,dalam kontraksi akan nampak bahwa terjadi suatu gerakan dari anggota-anggota tubuh yang disebabkan memanjang dan memendeknya otot-otot sehingga terdapat perubahan dalam panjang otot. Kontraksi ini disebut juga kontraksi dinamis. (3) kontraksi isokinetis yaitu kontraksi dari kedua kontraksi tersebut.

Tubuh manusia itu memiliki batas kemampuan maksimal dan membutuhkan waktu untuk beristirahat, selain untuk mengembalikan kekuatan otot, juga untuk meregenerasi otot-otot yang telah dirusak selama latihan, sehingga terbentuk otot baru yang memiliki kualitas yang lebih bagus dari sebelumnya. Disini dituntut suatu pengaturan keseimbangan antara latihan, gaya hidup dan istirahat dari seorang atlet. Faktor pemulihan sangat penting terhadap keberhasilan atlet. Karena pemulihan berkaitan dengan pembentukan cadangan energi dan kesegaran otot untuk mengadapi suatu pertandingan. Pengembangan teknik recovery pada dasarnya bertujuan untuk meningkatkan adaptasi atlet terhadap stress fisik maupun mental baik pada fase kompetisi maupun latihan (Murray, 2009).

Loading-recovery merupakan titik kunci dari proses latihan. Selain istirahat murni dengan pemuliahan pasif, beberapa strategi dan metode telah diusulkan bagi olahragawan untuk meningkatkan pemulihan fungsi otot setelah latihan maupun kompetisi (Hartono, 2012). Optimalisasi masa recovery sejalan dengan kajian teoritik yang menyatakan bahwa pengkondisian fisiologis atlet tidak hanya dilakukan pada masa latihan tapi juga pada masa recovery 
latihan, masa pertandingan, dan masa recovery antara pertandingan.

\section{PEMBAHASAN}

\section{A. Kekuatan Otot dalam Sepakbola}

Menurut Faizal (2012) kekuatan atau strenght adalah komponen kondisi fisik, yang menyangkut masalah kemampuan seseorang atlet pada saat mempergunakan otot-ototnya menerima beban dalam waktu kerja tertentu. Kekuatan merupakan salah satu unsur kondisi fisik yang sangat penting dalam berolahraga karena dapat membantu meningkatkan komponen-komponen seperti kecepatan, kelincahan dan ketepatan.

Kekuatan harus mutlak diperlukan pada setiap atlet untuk semua cabang olahraga. Kekuatan otot merupakan komponen penting dari kesegaran jasmani, karena tingkat penyesuaian kemampuan terjadi sesuai dengan proporsi dari kualitas dan jumlah serabut otot. Kekuatan dapat diartikan sebagai kualitas tenaga otot atau sekelompok otot dalam membangun kontraksi secara maksimal untuk mengatasi beban yang datang baik dari dalam maupun dari luar. Otot merupakan suatu organ atau alat yang memungkinkan tubuh dapat bergerak. Sebagian otot tubuh ini melekat pada kerangka otot yang dapat bergerak secara aktif sehingga dapat menggerakan bagian-bagian kerangka dalam suatu letak tertentu.

Pada sepakbola, kekuatan otot yang paling berperan adalah kekuatan otot tungkai. Kekuatan otot tungkai merupakan kemampuan otot untuk menerima beban dalam waktu bekerja di mana kemampuan itu dihasilkan oleh adanya kontraksi otot yang terdapat pada tungkai, kontraksi ini timbul untuk melakukan gerakan yang mendukung. Andi Suhendro (2004) mengatakan salah satu unsur kondisi fisik yang perlu dilatih terlebih dahulu adalah unsur kondisi fisik kekuatan, karena kekuatan memiliki peranan yang penting dalam melindungi atlet dari cedera serta membantu stabilitas sendi-sendi. Harsono dalam Yoga Parwata
(2015) kontraksi otot dapat digolongkan dalam tiga kategori yaitu: (1) kontraksi isometris, dalam kontraksi isometris otototot tidak memanjang atau memendek sehingga tidak nampak suatu gerakan yang nyata, atau dengan perkataan lain tidak ada jarak yang ditempuh. Kontraksi ini disebut juga kontraksi statis. (2) kontraksi isotenis,dalam kontraksi akan nampak bahwaterjadi suatu gerakan dari anggotaanggota tubuh yang disebabkan memanjang dan memendeknya otot-otot sehingga terdapat perubahan dalam panjang otot. Kontraksi ini disebut juga kontraksi dinamis. (3) kontraksi isokinetis yaitu kontraksi dari kedua kontraksi tersebut.

kontraksi dengan cepat, apabila ia mendapatkan rangsangan dari luar berupa rangsangan arus listrik, rangsangan mekanis, dingin dan lain-lain. Tarwoto (2009) mengatakan bahwa dalam keadaan sehari-hari otot ini bekerja atau berkontraksi menurut pengaruh atau perintah yang datang dari susunan saraf motoris. Berikut adalah gambar otot tungkai:

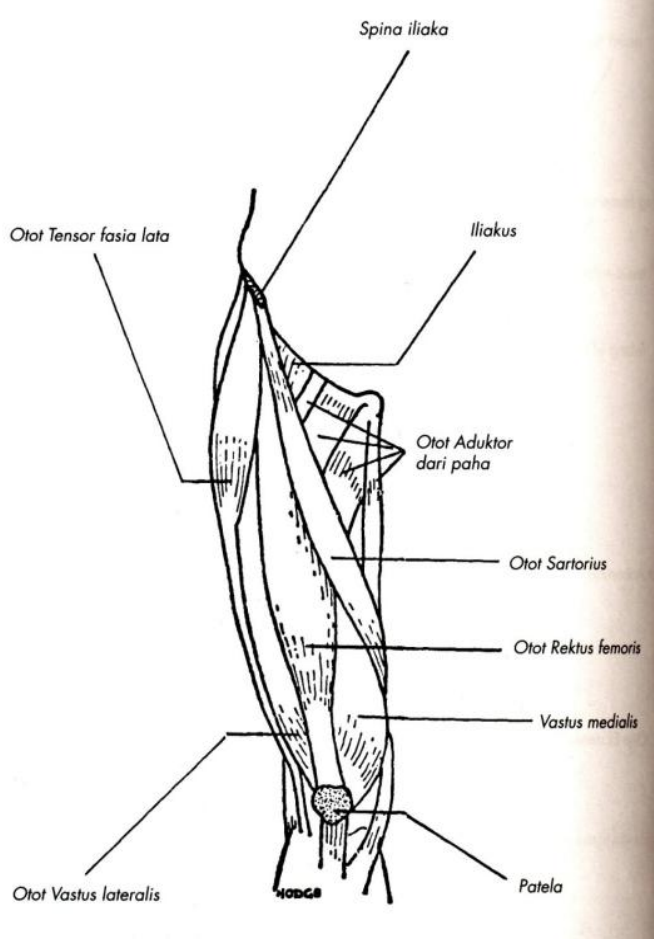

Gambar 1. Otot Tungkai Atas

(Pearce, Evelyn C., 2013) 


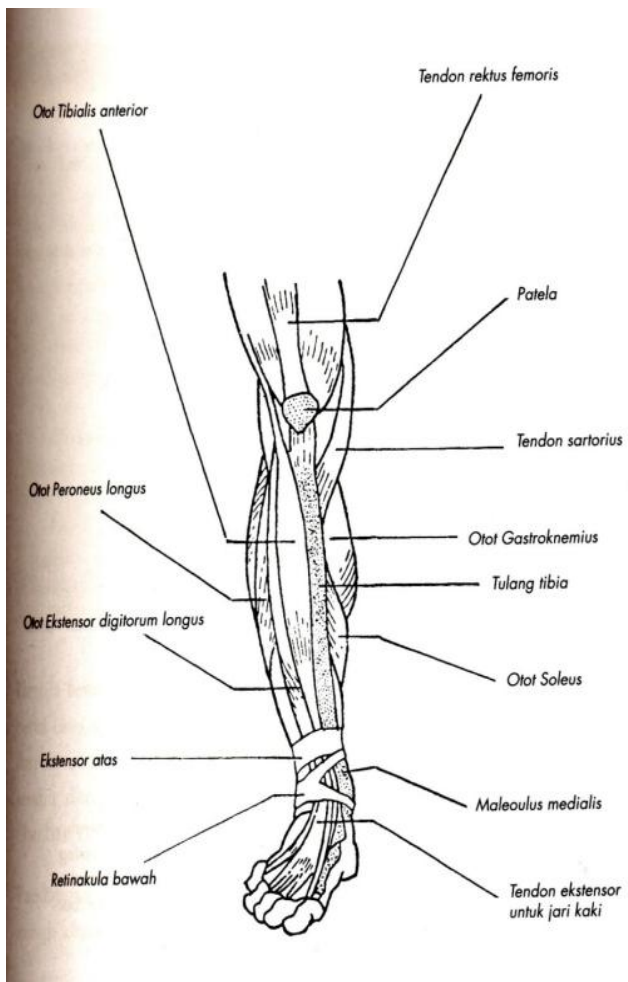

Gambar 2. Otot Tungkai Bagian Bawah (Pearce, Evelyn C., 2013)

\section{B. Pemulihan (Recovery)}

Ketika kita melakukan program latihan fisik yang berat, hal yang perlu diperhatikan selain trus menerus menggenjot latihan fisik adalah fase recovery (istirahat) bagi atlet. Hal yang kadang tidak diketahui adalah pendapat bahwa dengan terus menerus menggenjot fisik tanpa memperhitungkan istirahat dengan tujuan untuk mendapat kualitas fisik yang tinggi adalah hal yang salah besar. Tubuh manusia itu memiliki batas kemampuan maksimal dan membutuhkan waktu untuk beristirahat, selain untuk mengembalikan kekuatan otot, juga untuk meregenerasi otot-otot yang telah dirusak selama latihan, sehingga terbentuk otot baru yang memiliki kualitas yang lebih bagus dari sebelumnya. Berlatih merupakan kewajiban bagi seorang, setidaknya dua kali sehari. Runinitas ini berdampak kepada atlet baik fisiologis maupun psiologis.

Disini dituntut suatu pengaturan keseimbangan antara latihan, gaya hidup dan istirahat dari seorang atlet. Faktor pemulihan sangat penting terhadap keberhasilan atlet. Karena pemulihan berkaitan dengan pembentukan cadangan energi dan kesegaran otot untuk mengadapi suatu pertandingan. Pengembangan teknik recovery pada dasarnya bertujuan untuk meningkatkan adaptasi atlet terhadap stress fisik maupun mental baik pada fase kompetisi maupun latihan (Murray, 2009). Loading-recovery merupakan titik kunci dari proses latihan. Selain istirahat murni dengan pemuliahan pasif, beberapa strategi dan metode telah diusulkan bagi olahragawan untuk meningkatkan pemulihan fungsi otot setelah latihan maupun kompetisi (Hartono, 2012). Optimalisasi masa recovery sejalan dengan kajian teoritik yang menyatakan bahwa pengkondisian fisiologis atlet tidak hanya dilakukan pada masa latihan tapi juga pada masa recovery latihan, masa pertandingan, dan masa recovery antara pertandingan.

Optimalisasi teknik recovery penting untuk dilakukan mengingat kualitas recovery yang baik dapat menurunkan kelelahan baik secara obyektif indeks kelelahan) maupun subyektif (rating of perceived exertion), meningkatkan adaptasi fisiologis tubuh terhadap latihan fisik serta mengurangi resiko cedera (Hartono, 2012). Pada akhirnya, tantangan kurang optimalnya masa recovery pada saat pertandingan harus dijawab dengan menemukan formulasi strategi recovery yang paling optimal. Pelatihan yang efektif memerlukan penanganan yang terus menerus, makna yang permanaen dari recovery. Recovery mempercepat proses. Recovery setelah latihan dan pertandingan untuk mempertahankan kondisi fisik dan psikologis dalam status tertinggi. Maka recovery harus mengikuti kaidah - kaidah sebagai berikut:

1. Pertukaran yang rasional antara kerja dengan fase regenerasi.

2. Kesempatan untuk mengilangakan tekanan social.

3. Membuat suasana tim yang menyenangkan tentang percaya, dan pemain yang penuh optimistik.

4. Diet yang rasional dan bervariasi sesuia dengan cabang olahraga dan fase latihan. 
5. Istirahat aktif dalam suasana yang menyenangkan aktivitas social yang ringan.

6. Pemantauan yang terus menerus terhadap kondisi kesehatan atlet.

Proses recovery adalah proses multidimensi yang tergantung pada faktor intrinsik dan ekstrinsik. Dalam latihan atau masa pertandingan faktor pemulihan memegang peranan yang sangat penting. Dalam hal pengisian atau pemulihan energi memerlukan waktu. Pemulihan atau recovery adalah mengembalikan kondisi tubuh untuk siap untuk melakukan suatu aktivitas berikutnya.

Pemulihan dapat dibagi menjadi tiga yang terdiri dari :

1. Pemulihan cadangan energi

Pemulihan cadangan

energi dalam tubuh dapat dilakukan dengan adanya fase pemulihan maka sistem energi dapat melakukan pengisian cadangan energi dengan proses metabolisme. untuk bergerak ini tersedia melalui simpanan energi yang terdapat di dalam tubuh yaitu simpanan phosphocreatine (PCr), karbohidrat, lemak dan protein, molekul ATP ini akan dihasilkan melalui metabolism energi yang akan melibatkan beberapa reaksi kimia yang kompleks. Pengunaan simpanansimpanan energi tersebut beserta jalur metabolism energi yang akan digunakan menghasilkan molekul ATP ini juga akan bergantung terhadap jenis aktivitas serta intensitas yang dilakukan saat berolahraga (Irawan, 2007).

\section{ATP} merupakan satusatunya sumber energi yang digunakan secara langsung untuk aktivitas kontraksi otot. Di jaringan otot, ATP yang tersedia untuk dapat segera digunakan terbatas dan ATP tidak dapat disimpan. Oleh karena itu ATP harus terus menerus diproduksi (Ervana, 2010). Penyedian energi dalam tubuh bergantung pada sistem metabolisme yang terjadi di dalam sel otot. Dan energi sebagai penunjang utama untuk bergerak dihasilkan lewat proses metabolisme yang terjadi di otot Sistem energi tubuh sangat penting untuk diketahui, agar kita dapat mengerti batasan- batasan aktivitas fisik.

Ada tiga macam energi tubuh: (1) sistem phosphagen atau ATP Phosphocreatin, (2) sistem glikogen asam laktat atau sistem glikolisis dan (3) sistem aerobik atau sistem oksidatif (fosforilasi oksidatif). Sistem phosphagen dan sistem glikogen asam laktat dapat berjalan dengan tanpa adanya oksigen, karena itu dikatakan juga sebagai metabolism anaerobik atau sistem anaerobik (Rismayanthi, 2013).

Zat adenosine trifosfat (ATP) memainkan peranan kunci dalam membuat energi. ATP merupakan senyawa kimia labil yang terdapat di dalam semua sel (Guyton, 2013). Struktur ATP terdiri dari tiga bagian utama: (a) adenine, (b) ribose, (c) tiga buah phosphat, yang ketiganya berikatan bersama-sama. Pembentukan ATP terjadi dengan mengkombinasikan adenosine diphosphat (ADP) dan phosphate inorganic (Pi). Reaksi ini membutuhkan sejumlah energi.

2. Recovery aktif.

Recovery aktif adalah latihan dengan intensitas rendah atau ringan . pemulihan aktif ( recovery) mengacu pada pemulihan dari latihan menggunakan intensitas kegiatan rendah dengan tujuan untuk pemulihan. Pemulihan aktif membantu membersihkan otot-otot dari asam laktat yang menyebabkan rasa sakit dan kelelahan. Dapat dilakukan dengan aktivitas jogging. Pemulihan aktif dapat membantu : a. Rasa nyeri otot dapat hilang lebih cepat. b. Membantu otot memperbaiki jaringan yang rusak. c. Meningkatkan pemulihan psikologis / mental. d. Meningkatkan relaksasi mental dan fisik (Setiawan, 2011). Pemulihan aktif atau penurunan panas dengan latihan ringan lebih efisien dalam menambah pemulihan setelah latihan (Bompa, 2009).

3. Recovery Pasif.

Recovery pasif yaitu latihan yang tidak melibatkan aktifitas atau dilakukan duduk diam atau aktifitas istirahat total. Jadi recovery pasif yaitu suatu aktivitas fisik tanpa adanya aktifitas fisik, yaitu diam, istirahat total (duduk, terlentang atau tidur). Atau tidak melakukan apapun. Pengaruh pemulihan 
pasif. Terhadap otot (kelelahan otot) agar dapat pulih kembali seperti semula. Prinsip dari pemulihan pasif hampir sama dengan pemulihan aktif. Mengembalikan lagi kondisi fisik semula (Setiawan, 2011). Tidur adalah teknik utama dalam pemulihan pasif, tidur memiliki peranan sentral dalam membantu pemulihan atlet (Bompa, 2009).

\section{Teknik teknik Pemulihan}

Ada berapa cara atau macam teknik recovery yang dapat dilaksanakan dilapangan pada atlet untuk membantu proses pemulihan dengan teknik Recovery Physiotherapeutic diantaranya adalah sebagai berikut :

1 Massage

Adalah manipulasi sistematis dari jaringan tubuh yang lembut dan memberikan kemudahan dalam menghilangkan racun sisa proses metabolisme dan sampah yang tersisa akibat kerusakan jaringan. Bisa dilakukan $15-20$ menit sebelum latihan, setelah pemanasan umum 8 10 menit setelah mandi seusai latihan dan 20 - 30 menit atau lebih setelah mandi air panas atau sauna.

2 Heat atau thermotherapy.

Sauna memberikan efek pada sistem saraf dan endoktrin serta member pengaruh pada organ dan jaringan otot local. Pemanasan langsung mandi air panas atau steam bath pada suhu 36 derajat celcius selama $8-10$ menit akan menyebabkan otot lebih rilek.

3 Cold atau cryotherapy. Adalah teknik di mana peredaman air dingin atau mandi es digunakan untuk mengobati trauma akut dan teknik pemulihan .

\section{KESIMPULAN}

Kekuatan otot merupakan salah satu kondisi fisik yang dibutuhkan bagi seorang atlet sepakbola. Kekuatan otot dapat ditingkatkan melalui latihan. Latihan secara terus menerus tanpa pemulihan yang cukup dapat menyebabkan kerusakan pada otot. Pemulihan atau recovery merupakan hal penting bagi seorang atlet. Tubuh manusia itu memiliki batas kemampuan maksimal dan membutuhkan waktu untuk beristirahat, selain untuk mengembalikan kekuatan otot, juga untuk meregenerasi otot-otot yang telah dirusak selama latihan, sehingga terbentuk otot baru yang memiliki kualitas yang lebih bagus dari sebelumnya.

\section{DAFTAR PUSTAKA}

Andi Suhendro. 2004. Dasar-dasar Kepelatihan. Jakarta: Universitas Terbuka.

Bompa, T. O., Harf, G.G. 2009.Periodization Theory and Methodology of Training. Fifh Edition. United State of America: Human kinetics.

Ervana, A. 2010. Efektivitas Pemberian ATP dari Luar Terhadap Pemulihan Kelelahan Otot Gastrocnemius Rana Sp. Bogor : FKH IPB.

Faizal Chan. 2012. Strength Training (Latihan Kekuatan). Cerdas Saifa Ed. No. 1.

Hartono, Widiyanto, Suprijanto. 2012. Perubahan Kadar Asam Laktat Darah dan Performa Anaerobik Setelah Recovery Oksigen Hiperbarik dan Recovery Aktif. Jurnal IPTEK Olahraga. Vol. 14. No. 2.

Irawan, A. 2007. Metabolisme Energi Tubuh dan Olahraga. Sports Science Brif. Vol 02. No 07.

Luxbacher, Joseph. 2011. Sepakbola. Jakarta: PT. Raja Grafindo Persada.

Murray, R. K., Granner, D. K., \& Rodwell, V. W. 2009. Biokimia Harper Ed. 27. Jakarta: Buku Kedokteran EGC.

Pearce, Evelyn C. 2013. Anatomi dan Fisiologi untuk Paramedis. Jakarta: PT. Gramedia Pustaka Utama.

PSSI. 2009 . Peraturan Permainan Sepak Bola. Jakarta.

Setiawan, 2011. Pengaruh recovery aktif dan recovery pasif terhadap Penurunan Kadar CK pada cabag Atletik Nomor Lari jarak Jauh DKI. Jakarta: UNJ. 
Tarwoto, Ayani, R. \& Wartonah. 2009.

Anatomi dan Fisiologi Untuk

Mahasiswa Keperawatan.

Jakarta: Trans Info Media.

Yoga Parwata. 2015. Kelelahan dan

Recovery dalam Olahraga.

Jurnal Pendidikan Kesehatan

Rekreasi Vol. 1. 